\title{
Pathological Lesions and Inducible Nitric Oxide Synthase Expressions in the Liver of Mice Experimentally Infected with Clonorchis sinensis
}

\author{
Qing-Li Yang ${ }^{1,2}$, Ji-Qing Shen ${ }^{3}$, Yan Xue³, Xiao-Bing Cheng ${ }^{3}$, Zhi-Hua Jiang², Yi-Chao Yang², Ying-Dan Chen', \\ Xiao-Nong Zhou ${ }^{1, *}$ \\ ${ }^{1}$ National Institute of Parasitic Disease, Chinese Center for Disease Control and Prevention; Key Laboratory of Parasite and Vector Biology, Ministry \\ of Health; WHO Collaborating Centre for Malaria, Schistosomiasis and Filariasis, Shanghai 200025, P. R. China; 'Guangxi Zhuang Autonomous \\ Region Center for Disease Prevention and Control; Guangxi Key Laboratory for the Prevention and Control of Viral Hepatitis, Nanning 530028, P. R. \\ China; ${ }^{3}$ Department of Parasitology, Guangxi Medical University, Nanning 530021, P. R. China
}

\begin{abstract}
The nitric oxide (NO) formation and intrinsic nitrosation may be involved in the possible mechanisms of liver fluke-associated carcinogenesis. We still do not know much about the responses of inducible NO synthase (iNOS) induced by Clonorchis sinensis infection. This study was conducted to explore the pathological lesions and iNOS expressions in the liver of mice with different infection intensity levels of $C$. sinensis. Extensive periductal inflammatory cell infiltration, bile duct hyperplasia, and fibrosis were commonly observed during the infection. The different pathological responses in liver tissues strongly correlated with the infection intensity of $C$. sinensis. Massive acute spotty necrosis occurred in the liver parenchyma after a severe infection. The iNOS activity in liver tissues increased, and iNOS-expressing cells with morphological differences were observed after a moderate or severe infection. The iNOS-expressing cells in liver tissues had multiple origins.
\end{abstract}

Key words: Clonorchis sinensis, pathology, inducible nitric oxide synthase, liver, immunohistochemistry

Clonorchiasis is a food-borne zoonosis caused by Clonorchis sinensis, which is widely distributed in many east Asian countries [1-3]. In China, clonorchiasis has been identified as a severe public health problem in epidemic areas, such as the provinces of Guangdong, Guangxi, and Heilongjiang [3,4].

An etiological relationship possibly exists between clonorchiasis and cholangiocarcinoma (CCA) in human beings [57]. The possible mechanisms of liver fluke-associated carcinogenesis include chronic irritation, nitric oxide (NO) formation, intrinsic nitrosation, and so on [7]. Some studies confirmed that NO is not only involved in various physiological functions and signaling pathways for the non-specific defense against various infections, but also related to tumorigenesis [810]. Inducible NO synthase (iNOS) is responsible for the production of large quantities of NO upon stimulation under

- Received 14 January 2015, revised 29 June 2015, accepted 24 August 2015.

*Corresponding author (ipdzhouxn@sh163.net)

(c) 2015, Korean Society for Parasitology and Tropical Medicine

This is an Open Access article distributed under the terms of the Creative Commons Attribution Non-Commercial License (http://creativecommons.org/licenses/by-nc/3.0) which permits unrestricted non-commercial use, distribution, and reproduction in any medium, provided the original work is properly cited. pathologic conditions [11]. Accumulated evidence suggests that the expressions of iNOS are increased during helminth infections. iNOS is activated in the pathology of skeletal muscle tissue, and positive immunostaining for iNOS occurs in infiltrating mononuclear cells around the encapsulated larvae in experimental trichinellosis $[12,13]$. iNOS reactivities in epithelial cells are also induced in Toxocara canis-infected mice [14], and the enhanced iNOS expression seems to play a certain role in pathological damage in toxocaral granulomatous hepatitis [15]. The expression of iNOS is strongly induced in cattle reinfected with Cooperia oncophora [16]. However, the expressions of iNOS induced by cestodes are complex [17-19]. Meanwhile, the iNOS responses induced by $C$. sinensis have not received much attention. Therefore, the present study aims to understand iNOS responses in cellular sources and expression patterns in liver tissues of mice under different intensity levels of $C$. sinensis infection.

Metacercariae of C. sinensis were collected from Pseudorasbora parva captured in the Wang Tian Tang reservoir in Heng County, an endemic area of $C$. sinensis infection in Guangxi, China. The whole flesh of fish was digested with artificial gastric juice, 
and C. sinensis metacercariae were collected as previously described [20]. Groups of 24-30 BALB/c mice [21-23] (female) were inoculated with 20,40, or 80 metacercariae of $C$. sinensis in $100 \mu \mathrm{l}$ of $0.9 \% \mathrm{NaCl}$ via oral gavage to mimic mild, moderate, and severe infections, respectively. Mice gavaged with only $0.9 \% \mathrm{NaCl}$ served as controls. All animal study protocols were approved by the Institutional Animal Care and User Committees of Guangxi.

Stool samples were collected every other day from each infection group and pooled together every 10 days. For complete mixing, $1 \mathrm{ml}$ of sterile water was added to $1 \mathrm{~g}$ of stool for each sample. The stool samples were thoroughly mixed after complete humidification. Triplicate Kato-Katz thick smears using standard $41.7 \mathrm{mg}$ templates [24] were prepared from each stool sample. The number of $C$. sinensis eggs was counted and presented as the geometric mean of eggs per $1 \mathrm{~g}$ of stool (GM EPG).

Liver tissues containing the liver parenchyma and hepatobiliary tissues were obtained, and NOS activity was detected using an NOS assay kit (KBQ Biotech Co., Beijing, China). In brief, approximately $0.5 \mathrm{~g}$ of liver tissues was washed twice with $0.9 \% \mathrm{NaCl}$ and completely homogenized with $2.0 \mathrm{ml}$ of $40 \mathrm{mM}$ potassium phosphate buffer (pH 7.2). After centrifugation, $0.6 \mathrm{ml}$ of the supernatant was taken and mixed with $0.8 \mathrm{ml}$ of $38.7 \%$ hemoglobin and $29.9 \%$ NADPH. The absorbance (A) was immediately measured at 401 and $421 \mathrm{~nm}$ in a $1 \mathrm{~cm}$ cuvette by using a dual wavelength spectrophotometer (UV759; Shanghai Precision Instruments Co., Shanghai, China). The data were recorded every $30 \mathrm{sec}$ for $3 \mathrm{~min}$. NOS activity $(\mathrm{nmol} / \mathrm{min})$ was calculated using the formula $\left(\mathrm{A}_{401}\right.$ at 30 $\mathrm{sec}-\mathrm{A}_{421}$ at $30 \mathrm{sec}-\left[\mathrm{A}_{401}\right.$ at $90 \mathrm{sec}-\mathrm{A}_{421}$ at $\left.\left.90 \mathrm{sec}\right]\right) \times 194.3$. To determine the activity of iNOS, $50 \mathrm{mg} / \mathrm{ml}$ of L-NAME $\left(\mathrm{N}^{\mathrm{G}}\right.$-nitro-L-arginine methyl ester, hydrochloride; Beyotime Institute Biotech., Haimen, China) was added to the supernatant to inhibit eNOS activity. NOS/iNOS activity was expressed as $\mathrm{nmol} / \mathrm{min}$ per gram of tissue.

Liver tissues for immunohistochemical (IHC) analyses of iNOS expression were fixed with $4 \%$ formaldehyde-PBS (pH
7.4). The tissues were embedded in paraffin, and serial $4 \mu \mathrm{m}$ thick sections were prepared. The sections were deparaffinized in xylene and rehydrated with a graded alcohol series before they were processed for IHC staining through an indirect immunoperoxidase procedure. In brief, the sections were treated with antigen retrieval reagents (Beyotime) at $95-100^{\circ} \mathrm{C}$ in a water bath for $20 \mathrm{~min}$. Endogenous peroxidases were inactivated by immersing the sections in 3\% $\mathrm{H}_{2} \mathrm{O}_{2}$-methyl alcohol for 15 $\mathrm{min}$. The sections to be used were incubated with immunol staining blocking buffer (Beyotime) for $1 \mathrm{hr}$ at room temperature and then incubated overnight at $4^{\circ} \mathrm{C}$ with 1:100 diluted rabbit polyclonal antibody to iNOS (ab95866; Abcam, Hong Kong, China). After washing, the sections were incubated with 1:50 diluted HRP-conjugated goat anti-rabbit IgG $(\mathrm{H}+\mathrm{L})$ (Sangon) for $1 \mathrm{hr}$ at room temperature. Finally, the chromogenic reaction was developed with freshly prepared diaminobenzidine (DAB) staining reagent (Biotech Well, Shanghai, China). All of the sections were counterstained with hematoxylin (CellChip Biotech. Co., Beijing, China).

Data are presented as mean \pm SEM. Paired-sample $t$-tests using SPSS 11.5 for Windows were used to test for significant differences. Comparisons were considered significant at $P \leq 0.05$ and highly significant at $P \leq 0.01$ or $P \leq 0.001$.

Fecal examination was performed to confirm the intensity of infection on the basis of the presence of $C$. sinensis eggs. Very few eggs emerged at 50 and 60 day post-infection (dpi), which rapidly disappeared after 70 dpi when inoculated with 20 metacercariae. In the mice infected with 40 or 80 metacercariae, a small amount of eggs appeared at 40 to $70 \mathrm{dpi}$ and then disappeared after $80 \mathrm{dpi}$ (Table 1).

The activity of NOS increased in mice infected with 40 metacercariae at $20 \mathrm{dpi}(P<0.05)$, gradually increased at 45 dpi $(P<0.01)$, and then peaked at $90 \mathrm{dpi}(P<0.001)$. The activity of NOS in mice infected with 80 metacercariae also increased $20 \mathrm{dpi}$, reached a peak at $45 \mathrm{dpi}(P<0.01)$, and then slightly decreased at 90 dpi $(P<0.05)$. However, mice infected with 20 C. sinensis metacercariae exhibited no changes in NOS

Table 1. Egg production capacities ${ }^{a}$ by experiment groups and the duration of infection

\begin{tabular}{|c|c|c|c|c|c|c|c|c|c|}
\hline No. of metacercariae & $\sim 10 \mathrm{dpi}^{\mathrm{b}}$ & $\sim 20$ dpi & 30 dpi & 40 dpi & 50 dpi & $\sim 60$ dpi & 70 dpi & 80 dpi & 90 dpi \\
\hline 20 & 0 & 0 & 0 & 0 & 13.2 & 3.63 & 0 & 0 & 0 \\
\hline 40 & 0 & 0 & 0 & 76.2 & 138.5 & 109.9 & 13.2 & 0 & 0 \\
\hline
\end{tabular}

aMeasured by the Kato-Katz egg counting technique [24] and presented as GM EPG.

bDay post-infection. 
A

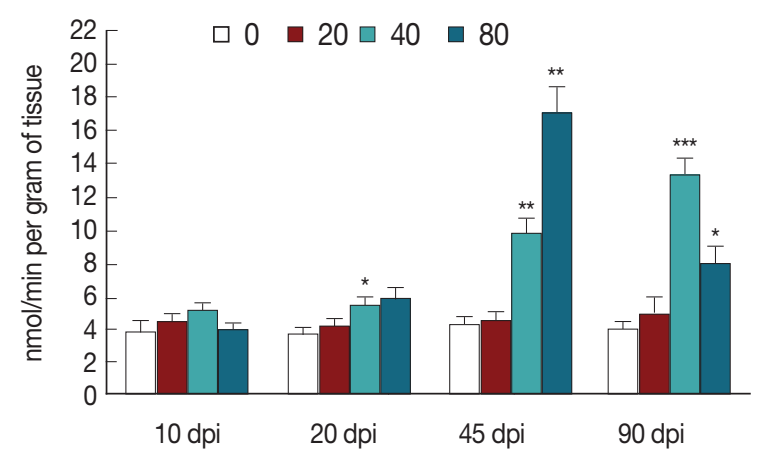

B

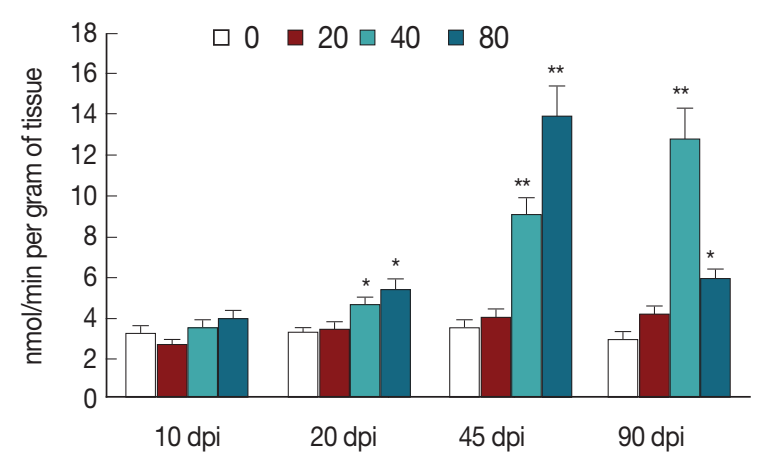

Fig. 1. iNOS activity in liver tissues of mice infected with $C$. sinensis. NOS (A) and iNOS (B) activities were detected and expressed as $\mathrm{nmol} / \mathrm{min}$ per gram of tissue with SEM bars. Significance was determined by comparison with uninfected controls. dpi, day post-infection. ${ }^{\star} P<0.05,{ }^{\star \star} P<0.01,{ }^{\star \star \star} P<0.001$.

activity in liver tissues (Fig. 1A). To determine iNOS expression, we analyzed the activity of NOS in the homogenate of liver tissues by suppressing eNOS. As expected, the changes in iNOS activity were consistent with those in NOS activity, but with a slight decrease because of eNOS inhibition $(P<0.05$, $P<0.01$; Fig. 1B).

Diverse pathological and iNOS responses were observed in the liver tissues of mice infected with C. sinensis. Massive/submassive inflammatory cell infiltration was observed in the liver portal tracts of mice infected with 20 metacercariae at 20 and $45 \mathrm{dpi}$, but this infiltration almost disappeared at $90 \mathrm{dpi}$. An obvious ductular adenomatous hyperplasia was also observed at 45 dpi. However, no positive cells for iNOS expression were detected in the liver specimens from mice with mild infections during the experiment (Fig. 2A). Severe periductal inflammatory responses were observed in the liver portal areas of mice infected with 40 metacercariae. Similarly, duct hyperplasia appeared at $45 \mathrm{dpi}$ and developed into extensive fibrous tissue hyperplasia at $90 \mathrm{dpi}$. Moreover, proliferating biliary epithelial cells (BECs) showed weak staining for iNOS at $45 \mathrm{dpi}$, but strong staining at $90 \mathrm{dpi}$ (Fig. 2B). Strong periductal inflammatory responses also occurred in the liver tissues of mice infected with 80 metacercariae. Wide regions of spotty necrosis in hepatic lobules were observed at $20 \mathrm{dpi}$. Many proliferated Kupffer cells (KCs) and/or sinusoidal endothelial cells (SECs) that showed negative staining for iNOS were observed in these necrotic foci. The universal ductular proliferation and fibrosis accompanied by liver regeneration and extensive inflammatory responses were observed at $45 \mathrm{dpi}$. Most of the proliferating $\mathrm{KCs} / \mathrm{SECs}$ showed strong staining for iNOS at $45 \mathrm{dpi}$. Other morphologically diverse cells in the proliferated/fibrous portal areas also showed strong staining for iNOS. These cells included spindled liver dendritic cells (LDCs), proliferated BECs, and $\mathrm{KCs} / \mathrm{SECs}$. The number of infiltrating inflammatory cells obviously reduced, whereas ductular fibrosis became severe at 90 dpi (Fig. 2C). No lesions were observed in the liver of the control mice (Fig. 2D).

In this study, we confirmed the usual lesions that occur in BALB/c mice infected with C. sinensis [2,21,22], and found that this infection also causes acute spotty necrosis and an obvious iNOS expression in liver tissues. The monocyte-macrophage system, which includes brain microglia, contains the primarily identified cells that express iNOS under stimulation $[25,26]$. This study demonstrated that iNOS can be expressed in many cell types in the liver of mice in response to $C$. sinensis infection; these cell types included BECs in the hyperplastic biliary tissues, spindle-shaped LDCs [27] localized within the portal area, and KCs and SECs in sinusoids. KCs are resident liver microphages that play crucial roles in the pathogenesis of liver diseases and influence the development of primary and metastatic liver tumors $[28,29]$. Several studies indicated that KCs produce various products, including cytokines, prostanoides, reactive oxygen species, and iNOS/NO, in response to infection, toxins, lipopolysaccharides, ischemia, and other stresses $[28,30,31]$. These factors regulate the phenotypes of KCs themselves, and influence the phenotypes of neighboring cells [28].

iNOS is induced by inflammatory mediators and is responsible for high and prolonged NO production [28]. NO generation and the subsequent formation of nitrite $\left(\mathrm{NO}_{2}^{-}\right)$and peroxynitrite $\left(\mathrm{ONOO}^{-}\right)$trigger histopathological changes, nitrosative tissue damages, and lipid peroxidation in the liver, as well as induce chromosomal aberrations $[25,32,33]$. NO production induced by TNF- $\alpha$ stimulation causes hepatic apoptosis but not necrosis. The exacerbation of hepatocyte cell death is 
A
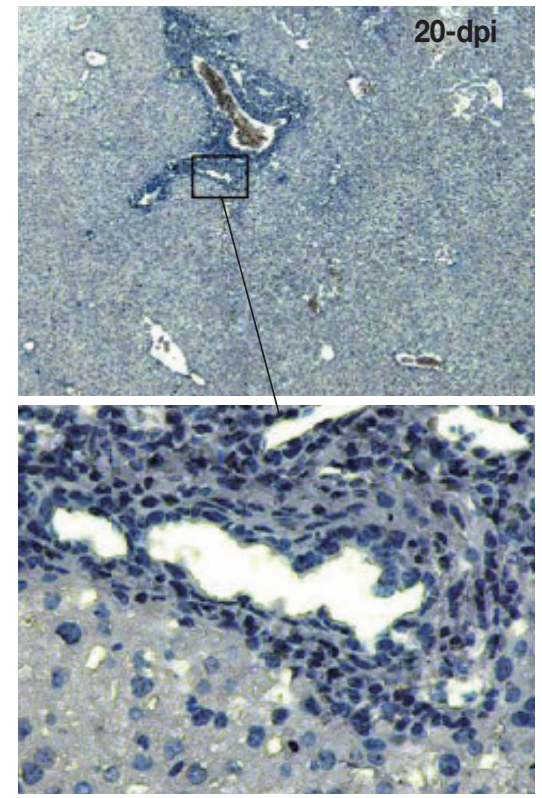

$\mathrm{B}$
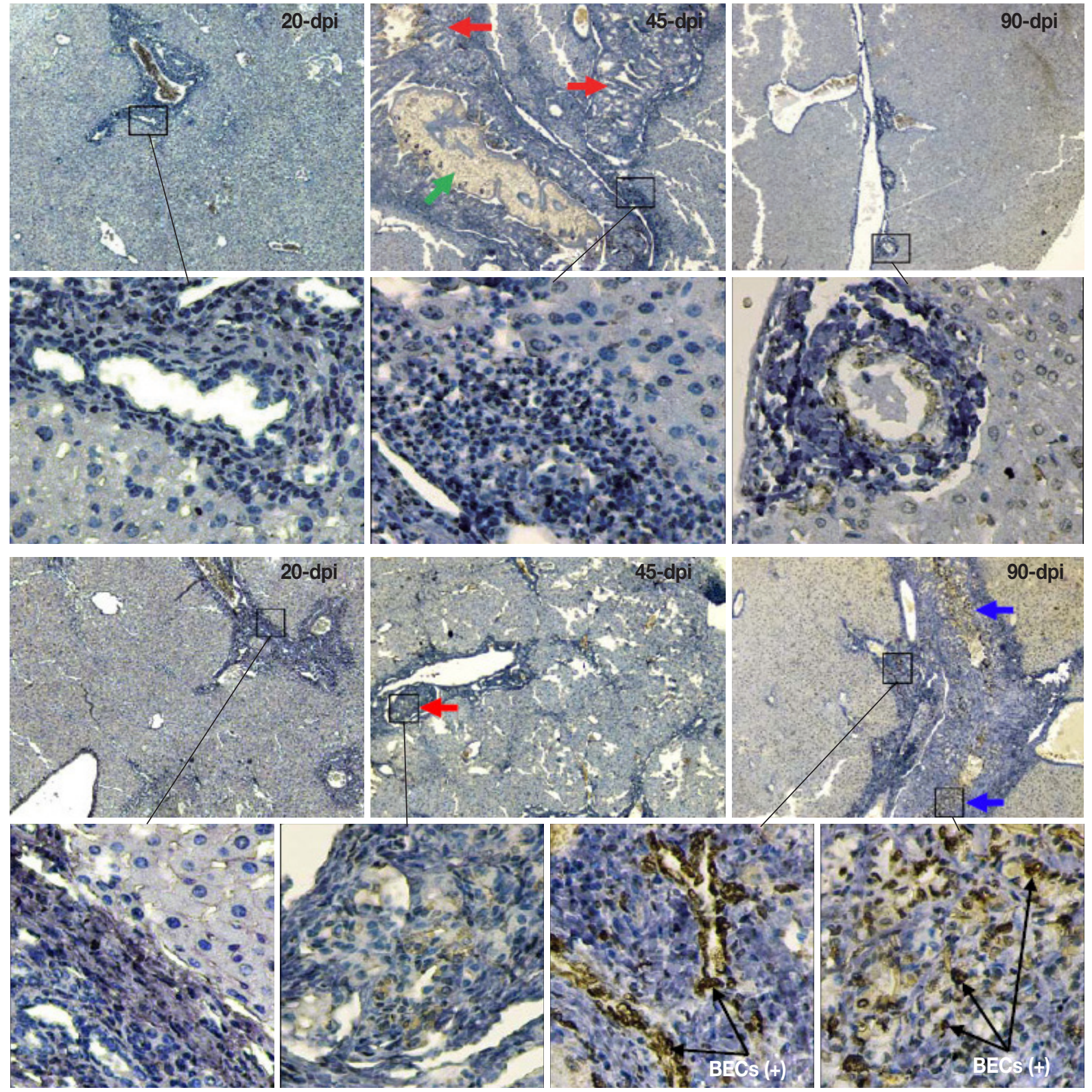

Fig. 2. Immunohistochemistry of iNOS in the liver of mice infected with C. sinensis. Liver sections were incubated with the antibody against iNOS and visualized by DAB as brown-colored deposits, and hematoxylin was used to counterstain the nuclei in blue. The pathological changes in the livers of mice infected with different numbers of metacercariae, namely, $20(A), 40(B)$, and 80 (C), were detected at 20, 45, and 90 days post-infection (dpi). Normal uninfected mice served as controls (D). The original magnification was at $40 x$, and the upper/lower corresponding images were magnified at $400 \times$. Arrows in red, blue, yellow, and green highlight the ductular adenomatous hyperplasia, fibrous tissue hyperplasia, spotty necrosis of hepatic lobules, and fluke, respectively. The figure shows 1 representative biopsy out of 6. SECs, sinusoidal endothelial cells; LDCs, liver dendritic cells; KCs, Kupffer cells; BECs, biliary epithelial cells. +, iNOS positive; -, iNOS negative.

(Continued to the next page)

caused by the co-culture with KCs but not related to TNF- $\alpha$ and NO [34]. These findings comply with our experimental results that liver necrosis simultaneously occurred with KCs proliferation but not with iNOS expression within the sinusoids. This result suggests that the intensive hepatic necrosis induced by severe infection was not caused by iNOS expression. KCs evidently participate in the pathogenesis of acute liver failure (ALF). Complex cell crosstalk occurs between KCs and neighboring cells, including hepatocytes, stellate cells, SECs, neutrophils, NK cells, NKT cells, and adaptive immune 

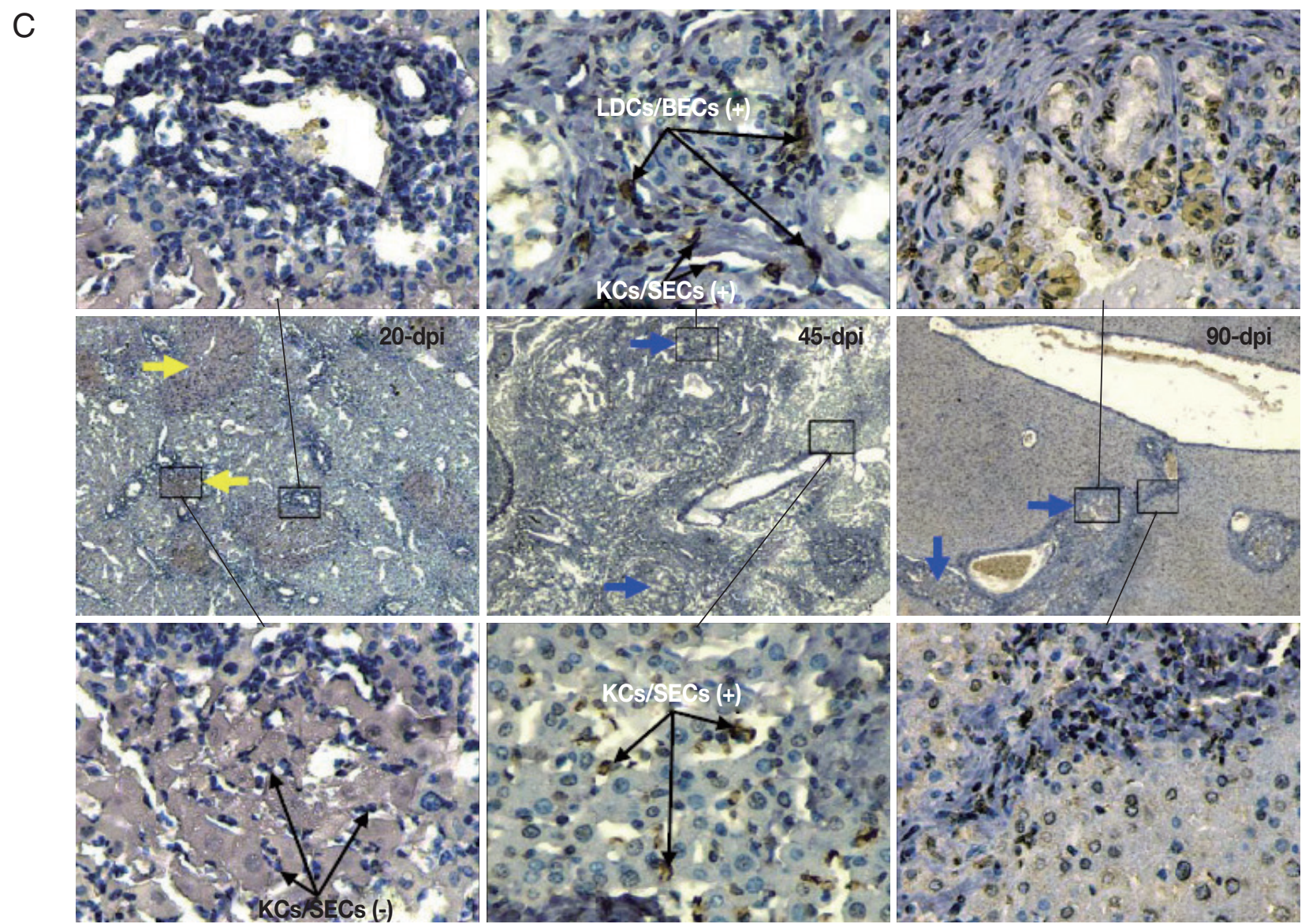

D
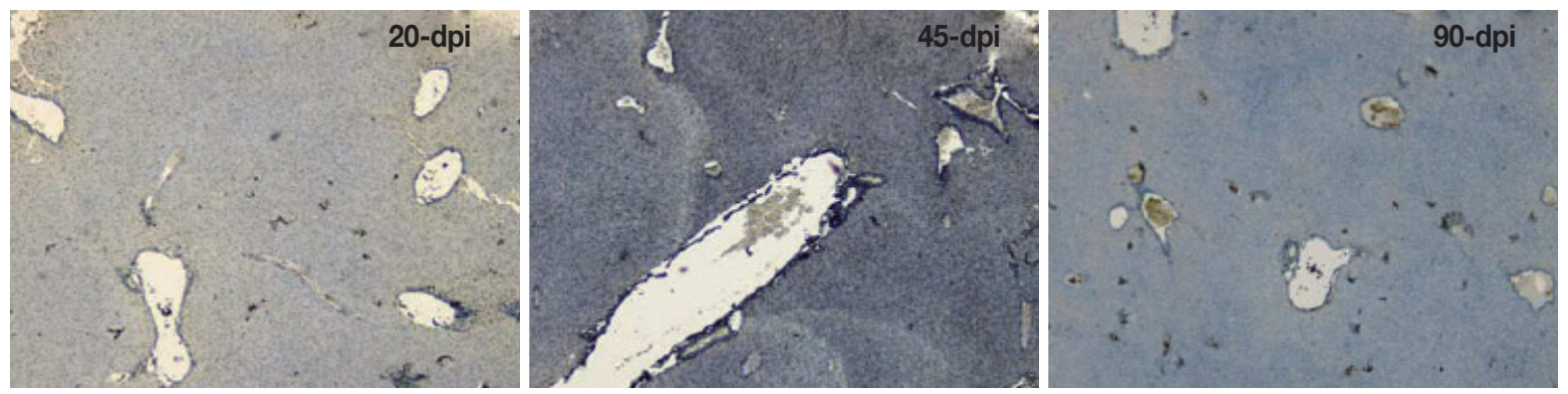

Fig. 2. (Continued)

cells, during the pathogenesis of ALF [28,35]. However, the characteristics of cell-cell interactions in ALF caused by C. sinensis infection are poorly understood.

Notably, iNOS expressions were only induced by moderate or severe infections and occurred at the later stage of infection. Considering the existence of a few adult worms at $40 \mathrm{dpi}$, we speculated that the observed iNOS expression may correspond to the development of these adult worms. However, the inconsistency between the iNOS expression in proliferated hepatobiliary tissues and the survival of adult worms after $80 \mathrm{dpi}$ is confusing. In fact, no adult worms survived at 80 dpi. Whether or not the iNOS response corresponds to the remaining eggs and/or the death of $C$. sinensis worms in the liver warrants further investigations.

Parasite-derived pathogen-associated molecular patterns (PAMPs) are recognized by pattern-recognition receptors (PRRs), such as toll-like receptors. These PAMPs stimulate the production of certain cytokines and participate in the pathogenesis of parasitic diseases [36]. Although the PAMPs from $C$. sinensis have not been identified, the presence of PAMPs is implied by the excretory-secretory products (ESPs) of C. sinensis. ESPs can translationally modulate several proteins with vari- 
ous biological functions [37] and induce the expression of the proinflammatory cytokines IL-1 $\beta$ and IL- 6 in an NF-kBdependent manner [38]. The iNOS/NO responses induced by C. sinensis ESPs were also caused by NF-kB activation [38]. These findings indicate that the PAMPs from parasites may activate certain gene expression pathways and induce iNOS expression by interacting with the PRRs. However, the C. sinensis PAMPs remain unidentified, and their presence in the eggs, larvae, and bodies needs to be verified. The results of this study may serve as a reference to characterize PAMPs from C. sinensis and elucidate the mechanisms underlying the development of clonorchiasis-associated CCA.

\section{ACKNOWLEDGMENTS}

This work was supported by research grants from the National Natural Science Foundation of China (No. 31260221) and the Natural Science Foundation of Guangxi (No. 2010GXNSFB013066).

\section{CONFLICT OF INTEREST}

We have no conflict of interest related to this work.

\section{REFERENCES}

1. Rim H J. Clonorchiasis: an update. J Helminthol 2005; 79: 269281.

2. Hong ST, Fang Y. Clonorchis sinensis and clonorchiasis, an update. Parasitol Int 2012; 61: 17-24.

3. Qian MB, Chen YD, Liang S, Yang GJ, Zhou XN. The global epidemiology of clonorchiasis and its relation with cholangiocarcinoma. Infect Dis Poverty 2012. doi: 10.1186/2049-9957-1-4.

4. Lun ZR, Gasser RB, Lai DH, Li AX, Zhu XQ, Yu XB, Fang YY. Clonorchiasis: a key foodborne zoonosis in China. Lancet Infect Dis 2005; 5: 31-41.

5. Choi BI, Han JK, Hong ST, Lee KH. Clonorchiasis and cholangiocarcinoma: etiologic relationship and imaging diagnosis. Clin Microbiol Rev 2004; 17: 540-552.

6. Sithithaworn P, Yongvanit P, Duenngai K, Kiatsopit N, Pairojkul C. Roles of liver fluke infection as risk factor for cholangiocarcinoma. J Hepatobiliary Pancreat Sci 2014; 21: 301-308.

7. Watanapa P, Watanapa WB. Liver fluke-associated cholangiocarcinoma. Br J Surg 2002; 89: 962-970.

8. Lirk P, Hoffmann G, Rieder J. Inducible nitric oxide synthasetime for reappraisal. Curr Drug Targets Inflamm Allergy 2002; 1: 89-108.
9. Lechner M, Lirk P, Rieder J. Inducible nitric oxide synthase (iNOS) in tumor biology: the two sides of the same coin. Semin Cancer Biol 2005; 15: 277-289.

10. Janakiram NB, Rao CV. iNOS-selective inhibitors for cancer prevention: promise and progress. Future Med Chem 2012; 4: 21932204.

11. Green SJ, Scheller LF, Marletta MA, Seguin MC, Klotz FW, Slayter M, Nelson BJ, Nacy CA. Nitric oxide: cytokine-regulation of nitric oxide in host resistance to intracellular pathogens. Immunol Lett 1994; 43: 87-94.

12. Boczoń K, Wandurska-Nowak E, Wierzbicki A, Frydrychowicz M, Mozer-Lisewska I, Zeromski J. mRNA expression and immunohistochemical localization of inducible nitric oxide synthase (NOS-2) in the muscular niche of Trichinella spiralis. Folia Histochem Cytobiol 2004; 42: 209-213.

13. Zeromski J, Boczoń K, Wandurska-Nowak E, Mozer-Lisewska I. Effect of aminoguanidine and albendazole on inducible nitric oxide synthase (iNOS) activity in T. spiralis-infected mice muscles. Folia Histochem Cytobiol 2005; 43: 157-159.

14. Demirci C, Gargili A, Kandil A, Cetinkaya H, Uyaner I, Boynuegri $\mathrm{B}$, Gumustas MK. Inhibition of inducible nitric oxide synthase in murine visceral larva migrans: effects on lung and liver damage. Chin J Physiol 2006; 49: 326-334.

15. Fan CK, Lin YH, Hung CC, Chang SF, Su KE. Enhanced inducible nitric oxide synthase expression and nitrotyrosine accumulation in experimental granulomatous hepatitis caused by Toxocara canis in mice. Parasite Immunol 2004; 26: 273-281.

16. Li RW, Li C, Gasbarre LC. The vitamin D receptor and inducible nitric oxide synthase associated pathways in acquired resistance to Cooperia oncophora infection in cattle. Vet Res 2011; 42: 48. doi:10.1186/1297-9716-42-48.

17. Dai WJ, Gottstein B. Nitric oxide-mediated immunosuppression following murine Echinococcus multilocularis infection. Immunology 1999; 97: 107-116.

18. Dai WJ, Waldvogel A, Jungi T, Stettler M, Gottstein B. Inducible nitric oxide synthase deficiency in mice increases resistance to chronic infection with Echinococcus multilocularis. Immunology 2003; 108: 238-244.

19. Soufli I, Toumi R, Rafa H, Amri M, Labsi M, Khelifi L, Nicoletti F, Touil-Boukoffa C. Crude extract of hydatid laminated layer from Echinococcus granulosus cyst attenuates mucosal intestinal damage and inflammatory responses in Dextran Sulfate Sodium induced colitis in mice. J Inflamm 2015; 12:19. doi: 10.1186/s12950-0150063-6.

20. Yang Q, Shen J, Jiang Z, Yang Y, Li H, Chen Y, Zhou X. Differentiation of Clonorchis sinensis metacercariae using PCR targeting ribosomal DNA ITS regions and COX1 gene. Chin J Parasitol Parasit Dis (in Chinese) 2014; 32: 217-220.

21. Choi YK, Yoon BI, Won YS, Lee CH, Hyun BH, Kim HC, Oh GT, Kim DY. Cytokine responses in mice infected with Clonorchis sinensis. Parasitol Res 2003; 91: 87-93.

22. Fu LL, Li Y, Liu YS, Tang RX, Du WP, Zheng KY, Xiao YS, Guo QQ, Dai QF. Establishment and comparison on mice model of 
Clonorchis sinensis. J Pathogen Biol (in Chinese) 2008; 3: 46-48.

23. Sohn WM, Zhang H, Choi MH, Hong ST. Susceptibility of experimental animals to reinfection with Clonorchis sinensis. Korean J Parasitol 2006; 44: 163-166.

24. Qian MB, Yap P, Yang YC, Liang H, Jiang ZH, Li W, Utzinger J, Zhou XN, Keiser J. Accuracy of the Kato-Katz method and formalin-ether concentration technique for the diagnosis of Clonorchis sinensis, and implication for assessing drug efficacy. Parasit Vectors 2013; 6: 314-319.

25. Förstermann U, Sessa WC. Nitric oxide synthases: regulation and function. Eur Heart J 2012; 33: 829-837.

26. Yang Q, Wei $P$, Chen $H$. Cytokine responses and inducible nitrous oxide synthase expression patterns in neonatal chicken brain microglia infected with very virulent Marek's disease virus strain YL040920. Vet Immunol Immunopathol 2011; 142: 14-24.

27. Lukacs-Kornek V, Schuppan D. Dendritic cells in liver injury and fibrosis: shortcomings and promises. J Hepatol 2013; 59: 11241126.

28. Bilzer M, Roggel F, Gerbes AL. Role of Kupffer cells in host defense and liver disease. Liver Int 2006; 26: 1175-1186.

29. Wen SW, Ager EI, Christophi C. Bimodal role of Kupffer cells during colorectal cancer liver metastasis. Cancer Biology \& Therapy 2013; 14: 606-613.

30. Shiratori Y, Ohmura K, Hikiba Y, Matsumura M, Nagura T, Okano K, Kamii K, Omata M. Hepatocyte nitric oxide production is induced by Kupffer cells. Dig Dis Sci 1998; 43: 1737-1746.

31. Valatas V, Kolios G, Manousou P, Xidakis C, Notas G, Ljumovic D, Kouroumalis EA. Secretion of inflammatory mediators by isolat- ed rat Kupffer cells: the effect of octreotide. Regul Pept 2004; 120: 215-225.

32. Nahrevanian H. Involvement of nitric oxide and its up/down stream molecules in the immunity against parasitic infections. Braz J Infect Dis 2009; 13: 440-448.

33. Ozen H, Kamber U, Karaman M, Gül S, Atakişi E, Ozcan K, Atakişi O. Histopathologic, biochemical and genotoxic investigations on chronic sodium nitrite toxicity in mice. Exp Toxicol Pathol 2014; 66: 367-375.

34. Abou-Elella AM, Siendones E, Padillo J, Montero JL, De la Mata M, Muntané Relat J. Tumour necrosis factor-alpha and nitric oxide mediate apoptosis by D-galactosamine in a primary culture of rat hepatocytes: exacerbation of cell death by cocultured Kupffer cells. Can J Gastroenterol 2002; 16: 791-799.

35. Yang Q, Shi Y, He J, Chen Z. The evolving story of macrophages in actte liver failure. Immunol Lett 2012; 147: 1-9.

36. Yang Q, Shen J. Pathogen associate molecular patterns of parasites. Chin J Parasitol Parasit Dis (in Chinese) 2013; 31: 238-241.

37. Pak JH, Moon JH, Hwang SJ, Cho SH, Seo SB, Kim TS. Proteomic analysis of differentially expressed proteins in human cholangiocarcinoma cells treated with Clonorchis sinensis excretory-secretory products. J Cell Biochem 2009; 108: 1376-1388.

38. Nam JH, Moon JH, Kim IK, Lee MR, Hong SJ, Ahn JH, Chung JW, Pak JH. Free radicals enzymatically triggered by Clonorchis sinensis excretory-secretory products cause NF-kB-mediated inflammation in human cholangiocarcinoma cells. Int J Parasitol 2012; 42: 103-113. 
